\title{
Risk Factors for Unintended Durotomy in Lumbar Spine Surgery
}

\author{
HUSSEIN SOFFAR, M.D.; MOHAMED ELMALLAWANY, M.D. and AYMAN TAREK MAHMOUD, M.D. \\ The Department of Neurosurgery, Faculty of Medicine, Cairo University
}

\begin{abstract}
Background: Unintended durotomy is the most frequent intraoperative complication during lumbar spine surgery reaching up to $16 \%$ in some studies. It must be managed properly by the surgeon intraoperatively and postoperatively.

Aim of Study: The aim of the study is to recognize the risk factors for unintended durotomies in lumbar spine surgery.

Patients and Methods: The study was conducted over 263 patients who were operated upon for lumbar spine degenerative disease, from which data was collected including age, type of surgery, associated medical disorders.
\end{abstract}

Results: Discectomy was done for 65 patients and laminectomy was done for 198 patients. Four cases had durotomy in the discectomy patients while 29 cases had unintended durotomy in the laminectomy patients. The incidence was higher in older patients (mean $65 \pm 13$ vs $53 \pm 14$ years of age). Unintended durotomy is more in revision surgery.

Conclusion: The incidence of unintended durotomy is more in laminectomy, recurrent surgeries, lumbar fixation and older age.

Key Words: Unintended durotomy - Lumbar-Recurrent.

\section{Introduction}

UNTENDED durotomy and subsequent CSF leak is the most frequent intraoperative complication during lumbar spine surgery ranging from $2.1 \%$ to $15.9 \%$ in some studies $[\mathbf{1 , 2}, \mathbf{4}]$. If not appropriately treated, CSF leak may lead to various effects such as subcutaneous collection, meningitis, abscess formation, arachnoiditis, improper wound healing, headache and neurological defects $[3,5]$ so, it is important for the surgeon to be cautious about the risk factors for unintended durotomy and to be familiar with safe and effective techniques to close the dura and further postoperative management [6,9]. Although, there are many possible negative effects of unintended durotomy, proper diagnosis and management both intraoperative and postop-

Correspondence to: Dr. Hussein Soffar, The Department of Neurosurgery, Faculty of Medicine, Cairo University erative significantly decrease postoperative morbidity $[7,8]$

Previous studies have examined many risk factors for unintended durotomy mainly age of the patient, type of surgery, prior lumbar surgery, length of surgery, the level of surgeon s training, smoking, body mass index (BMI) and associated medical disorders but most of these studies were in a retrospective manner [10-13]

\section{Patients and Methods}

This is a prospective interventional study conducted over 263 patients who had lumbar degenerative disorders underwent surgical intervention at our institution between January 2018 and June 2018.

We excluded patients who were operated for trauma, tumours, infection and high grade spondylolithesis.

History taking including age, sex, associated medical conditions and history of prior spinal surgery, length of surgery and postoperative headache were also recorded. The data collected and risk factors are compared regarding their effect on unintended durotomy.

\section{Results}

The study was conducted over 263 patients who were operated for degenerative lumbar spine disorders. Discectomy was done for 65 patients and laminectomy was done for 198 patients. Four cases $(6.1 \%)$ had durotomy in the discectomy patients while $29(14.6 \%)$ cases had unintended durotomy in the laminectomy patients. The operative time was longer in patients who had unintended durotomy ( $90 \pm 20$ minutes) compared to those who did not have unintended durotomy ( $55 \pm 15$ minutes). 
Table (1): Surgical procedure and unintended durotomy.

\begin{tabular}{lccc}
\hline Surgical procedure & $\begin{array}{c}\text { Total } \\
\text { number } \\
\text { of patients }\end{array}$ & $\begin{array}{c}\text { Number of } \\
\text { unintended } \\
\text { durotomy }\end{array}$ & $\begin{array}{c}\% \text { of } \\
\text { unintended } \\
\text { durotomy }\end{array}$ \\
\hline Microdiscectomy & 65 & 4 & $6.1 \%$ \\
Laminectomy & 198 & 29 & $14.6 \%$ \\
Primary surgery & 172 & 14 & $8.7 \%$ \\
Recurrent surgery & 91 & 19 & $20.8 \%$ \\
Laminectomy & 129 & 18 & $13.9 \%$ \\
$\quad$ (instrumented) & & & \\
Laminectomy & 69 & 11 & $15.9 \%$ \\
(non-instrumented) & & & \\
\hline
\end{tabular}

In the laminectomy group, the incidence of durotomy was $14.6 \%$ (29 patients out of 198 patients).

The mean age in patients with durotomy was ( $65 \pm 13$ years) versus ( $53 \pm 14$ years) in non durotomy group.

Surgery time was ( $140 \pm 40$ minutes) in durotomy versus ( $110 \pm 35$ minutes) in non durotomy patients.

Unintended durotomy is significantly higher in recurrent surgery [ 19 patients $(20.8 \%)$ of 91 patients] while only [14 patients $(8.1 \%)$ of 172 patients] in fresh surgeries.

Most of durotomies occurred during decompression while only 1 durtomy occurred during instrumentation.

The incidence is slightely higher in fixation. But, it has statistically insignificant effect on the incidence of durotomy $(p=0.532)$ for all cases of durotomy, closure was attempted and 18 (54.5\%) patients reported postoperative headache.

\section{Discussion}

In this study, data was collected from patients who were operated for degenerative lumbar spine disorders either laminectomy or discectomy with or without fixation. The incidence of unintended durotomy in our study is $(12.5 \%)$ which is slightly lower than other studies while, the incidence in Wang et al., [11] study was $14 \%$ (88 patients in a retrospective study of 641 patients). Another prospective study of Sin et al., [9] in 75 patients found the incidence of unintended durotomy to be $15.8 \%$.

Patient age is an important risk factor with higher incidence in older age, in our study we found that the incidence is higher in older age. This goes with Sin et al., [9] who found more incidence in the elderly $(p=0.02)$. This goes with Deyo et al., [3] who did a large study on 18122 patients for postoperative lumbar complications and revealed more incidence of unintended durotomy in older age. This might be due to more degenerative changes and thinner dura which is observed more in the elderly and in tight stenosis.

In our study, the incidence was higher in revision surgery $20.8 \%$ vs. $8.1 \%$. Mostly due to postoperative adhesions and loss of anatomical landmarks. This goes with Stolke et al., [10] in his study which revealed incidence of $5.3 \%$ in discectomies and $17.4 \%$ in recurrent surgeries. And also with Deyo et al., who reported higher incidence in revision surgeries. This doesn't go with Sin et al., and other similar studies $[3,5,8]$ who found no significant difference of the incidence of unintended durotomy in revision surgery.

So, the surgeon should be cautious in revision surgery especially in dealing with areas of dense scar tissues.

In our study the there was no statistical difference between decompression alone or decompression plus fixation. However, the incidence was strongly lower in patients who had discectomy (6.1\%) than patients who had laminectomy (14.6\%) this goes with Sin et al., [9] (4.6\% in discectomy patients and $12.8 \%$ in laminectomy patients).

It worth mentioning, that one case of microdiscectomy, who had unintended durotomy, had a conjoined nerve root. A study done by Lotan et al., [7] demonstrated higher incidence of a conjoined nerve root $(5.8 \%)$. So, preoperative suspicion of a conjoined nerve root is important to avoid unintended durotomy.

\section{Conclusion:}

Older age, recurrent surgeries and laminectomy are risk factors for unintended durotomy in which the surgeon should be cautious to avoid this complication.

\section{References}

1- GUERIN P., EL FEGOUN A.B., OBEID I., GILLE O., LELONG L., LUC S., et al.: Incidental durotomy during spine surgery: Incidence, management and complications. A retrospective review. Injury, 43: 397-401, 2012.

2- WILLIAMS B.J., SANSUR C.A., SMITH J.S., BERVEN S.H., BROADSTONE P.A., CHOMA T.J., et al.: Incidence of unintended durotomy in spine surgery based on 108,478 cases. Neurosurgery, 68: 117-124, 2011.

3- DEYO R.A., CHERKIN D.C., LOESER J.D., BIGOS S.J. and CIOL M.A.: Morbidity and mortality in association with operations on the lumbar spine. The influence of age, diagnosis, and procedure. J. Bone Joint Surg. Am., 74: 536-543, 1992. 
4- KHAN M.H., RIHN J., STEELE G., DAVIS R., DONALDSON W.F.III, KANG J.D., et al.: Postoperative management protocol for incidental dural tears during degenerative lumbar spine surgery: A review of 3,183 consecutive degenerative lumbar cases. Spine (Phila Pa 1976) 31: 2609-2613, 2006.

5- KALEVSKI S.K., PEEV N.A. and HARITONOV D.G.: Incidental dural tears in lumbar decompressive surgery: incidence, causes, treatment, results. Asian J. Neurosurg, 5: 54-59, 2010.

6- BAKER G.A., CIZIK A.M., BRANSFORD R.J., BELLABARBA C., KONODI M.A., CHAPMAN J.R., et al.: Risk factors for unintended durotomy during spine surgery: A multivariate analysis. Spine J., 12: 121-126, 2012.

7- LOTAN R., AL-RASHDI A., YEE A. and FINKELSTEIN J.: Clinical features of conjoined lumbosacral nerve roots versus lumbar intervertebral disc herniations. Eur. Spine J., 19: 1094-1098, 2010.

8- MORGAN-HOUGH C.V., JONES P.W. and EISENSTEIN S.M.: Primary and revision lumbar discectomy. A 16-year review from one centre. J. Bone Joint Surg. Br., 85: 871874, 2003.

9- SIN A.H., CALDITO G., SMITH D., RASHIDI M., WILLIS B. and NANDA A.: Predictive factors for dural tear and cerebrospinal fluid leakage in patients undergoing lumbar surgery. J. Neurosurg Spine, 5: 224-227, 2006.

10- STOLKE D., SOLLMANN W.P. and SEIFERT V.: Intraand postoperative complications in lumbar disc surgery. Spine (Phila Pa 1976), 14: 56-59, 1989.

11- WANG J.C., BOHLMAN H.H. and RIEW K.D.: Dural tears secondaryto operations on the lumbar spine. Management and results after a two-year-minimum followup of eighty-eight patients. J. Bone Joint Surg. Am., 80: 1728-1732, 1998.

12- CAMMISA F.P. Jr., GIRARDI F.P., SANGANI P.K., PARVATANENI H.K., CADAG S. and SANDHU H.S. Incidental durotomy in spine surgery. Spine (Phila $\mathrm{Pa}$ 1976) 25: 2663-2667, 2000

13- YOSSI S., KEVIN C. BAKER, et al.: Predisposing factors for dural tearin patients undergoing lumbar spine surgery. J. Neurosurg. Spine, 22: 483-6, 2015.

\section{عوا مل الخطورة للقطع غير الهقصود للأم الجافية

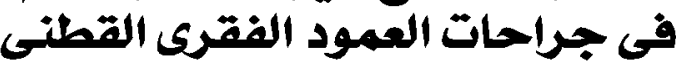

$$
\begin{aligned}
& \text { يعتبر القطع الغير مقصود للأم الجافية من أكثر المضاعفات شيوعاً التى تصدث أثناء إجراء الجراحة فى جراحات العمود الفقرى القطنى. } \\
& \text { حاولنا في هذا البحث دراسة عوامل الخطوة التى تؤدى إلى حدوث قطع غير مقصود للأم الجافية فى جراحات العمود الفقرى القطنى. } \\
& \text { شمل هذا البحث بحץ مريض خضعوا لجراحة في العمود الفقرى القطنى ودراسة مختلف عوامل الخطودة وخاصة السن والإجراء الجراحى. } \\
& \text { خلصت الدراسة إلى ارتفاع حالات القطع غير المقصود للأم الجافية في المرضى الآكبر سناً وعمليات استئصال الصفيحة العظمية والحالات } \\
& \text { المرتجعة وحالات تثبيث الفقرات القطنية. }
\end{aligned}
$$

